\title{
Modeling sensitivity study of the possible impact of snow and glaciers developing over Tibetan Plateau on Holocene African-Asian summer monsoon climate
}

\author{
L. Jin ${ }^{1}$, Y. Peng ${ }^{1}$, F. Chen ${ }^{1}$, and A. Ganopolski ${ }^{2}$ \\ ${ }^{1}$ Key Laboratory of Western China's Environmental Systems (Ministry of Education), Lanzhou Univ., Lanzhou 730000, China \\ ${ }^{2}$ Potsdam Institute for Climate Impact Research, Potsdam, Germany
}

Received: 13 October 2008 - Published in Clim. Past Discuss.: 11 December 2008

Revised: 15 June 2009 - Accepted: 23 June 2009 - Published: 21 August 2009

\begin{abstract}
The impacts of various scenarios of a gradual snow and glaciers developing over the Tibetan Plateau on climate change in Afro-Asian monsoon region and other regions during the Holocene ( 9 kyr BP-0 kyr BP) are studied by using the Earth system model of intermediate complexity, CLIMBER-2. The simulations show that the imposed snow and glaciers over the Tibetan Plateau in the mid-Holocene induce global summer temperature decreases over most of Eurasia but in the Southern Asia temperature response is opposite. With the imposed snow and glaciers, summer precipitation decreases strongly in North Africa and South Asia as well as northeastern China, while it increases in Southeast Asia and the Mediterranean. For the whole period of Holocene ( $9 \mathrm{kyr} \mathrm{BP}-0 \mathrm{kyr} \mathrm{BP})$, the response of vegetation cover to the imposed snow and glaciers cover over the Tibetan Plateau is not synchronous in South Asia and in North Africa, showing an earlier and a more rapid decrease in vegetation cover in North Africa from $9 \mathrm{kyr}$ BP to $6 \mathrm{kyr}$ BP while it has only minor influence on that in South Asia until $5 \mathrm{kyr}$ BP. The precipitation decreases rapidly in North Africa and South Asia while it decreases slowly or unchanged during 6 kyr BP to $0 \mathrm{kyr}$ BP with imposed snow and glacier cover over the Tibetan Plateau. The different scenarios of snow and glacier developing over the Tibetan Plateau would result in differences in variation of temperature, precipitation and vegetation cover in North Africa, South Asia and Southeast Asia. The model results suggest that the development of snow and ice cover over Tibetan Plateau represents an additional important climate feedback, which amplify orbital forcing and produces a significant synergy with the positive vegetation feedback.
\end{abstract}

Correspondence to: L. Jin

(jinly@lzu.edu.cn)

\section{Introduction}

Holocene climate change is one of the focus themes both in paleoclimate modeling and proxy data reconstruction communities. By examining 50 globally distributed paleoclimate records, Mayewski et al. (2004) revealed as many as six periods of significant rapid climate change during the Holocene which were synchronous of the whole Earth. It is suggested that changes in insolation related both to Earth's orbital variations and to solar variability played a central role in the global scale changes in climate of the last $11.5 \mathrm{cal} \mathrm{kyr}$ (Mayewski et al., 2004). This insolation driving mechanism in the Holocene climate change is supported by climate modeling experiments of African-Asian monsoon climate (e.g. Kutzbach and Otto-Bliesner, 1982; Kutzbach and Guetter, 1986; COHMAP Members, 1988; Joussaume et al., 1999; Otto-Bliesner, 1999; Weber et al., 2004). However, external forcing, e.g. the Earth's orbital variations and the solar variability, can be amplified and modified through a number of feedbacks within the climate system leading to marked climate variations in the Holocene (Foley et al., 1994; TEMPO Members, 1996; Claussen and Gayler, 1997; Ganopolski et al., 1998b; Wang, 1999). The atmospherevegetation feedback is an important amplifying factor of the North Africa's abrupt climate transition from a wet phase to a dry phase starting at around $6 \mathrm{kyrBP}$ (Texier et al., 1997; Claussen et al., 1999). The positive oceanic feedback is another factor for enhanced African summer monsoon in early Holocene (Kutzbach and Liu, 1997; Liu et al., 2003). Studies from lake sediment pollen and carbonate records showed the arid phase in South Asia probably started around 5 kyr BP (Maxwell, 2001; Singh, 2002), coinciding with a stepwise weakening of the southwest monsoon (Gupta and Anderson, 2005), which was closely linked to North Atlantic cold spells, e.g. the millennial-scale cold events during

Published by Copernicus Publications on behalf of the European Geosciences Union. 
4.6-4.2 kyr BP (Gupta et al., 2003). In addition, it is indicated that the so-called "Megathermal" or "Holocene Optimum" from 8.5-3.0 kyr BP often mentioned in the Chinese Quaternary and paleoclimate community (Huang, 1998; Qin, 2002), as defined by peak precipitation or effective moisture, is asynchronous in eastern Asian monsoon regions, which is related to a general weakening and southward retreat of the East Asian summer monsoon since about 9 kyr BP (An et al., 2000).

The Tibetan Plateau, with a mean elevation of $4.5 \mathrm{~km}$ above sea level and an area of $2.5 \times 10^{6} \mathrm{~km}^{2}$, is one of the most imposing topographic features in Central Asia and the greatest glaciated areas outside the Polar Regions. The Tibetan Plateau has a profound influence on regional and global atmospheric circulation and is therefore important for our understanding the dynamics of global environmental and climatic change (Ruddiman and Kuzbach, 1989; Molnar and England, 1990; Prell and Kutzbach, 1992; Yanai et al., 1992). Studies of glacier changes during the late Quaternary were conducted over the Tibetan Plateau and significant progress has been made in recent years (Lehmkuhl and Oven, 2005). Earlier study has revealed that there were intervals of glacier advances over the Tibetan Plateau during the Holocene at about 8.2-7.2 kyr BP, 5.8-4.9 kyr BP, $3 \mathrm{ky}$ $\mathrm{BP}$ and 300-450 yr BP, respectively (Lehmkuhl, 1997). Observation from the Dasuopu glacier $\left(28^{\circ} 23^{\prime} \mathrm{N}, 85^{\circ} 43^{\prime} \mathrm{E}\right)(1 \mathrm{o}-$ cated in the southwestern region of the Tibetan Plateau) shows a gradually increase of snow accumulation from AD 1600 to 1817 , and then a significant increase persisted until AD 1880 (Thompson et al., 2000). At another glacier site, the Guliya ice cap $\left(35^{\circ} 17^{\prime} \mathrm{N}, 81^{\circ} 29^{\prime} \mathrm{E}\right)$ which is located in northwestern region of the Tibetan Plateau and whose records is believed to cover more than 100000 years, spanning the whole Holocene to the last interglacial (Christner et al., 2003) showed a rapid decrease in temperature up to $3 \sim 4^{\circ} \mathrm{C}$ during the period of $7-5 \mathrm{kyr} \mathrm{BP}$ (Thompson et al., 1997; Yao et al., 2000). Glaciers at Nanga Parbat $\left(35^{\circ} 14^{\prime} 15^{\prime \prime} \mathrm{N}, 74^{\circ} 35^{\prime} 21^{\prime \prime} \mathrm{E}\right)$, north western Himalaya Mountains, expanded during the early to middle Holocene about 9.0-5.5 kyr BP (Phillips et al., 2000). Evidence from oxygen isotope records in the Bay of Bengal shows that during earlymiddle Holocene, the Himalayas experienced at least two significant episodes of aridity and intensified glaciation at 5$4.3 \mathrm{kyr}$ BP and about 2 kyr BP (Chauhan, 2003). Recently, evidence based on radiocarbon ages of fossil wood buried in moraines, lichen-dated moraines and tree ring identified three main periods of glacier advances in the southeastern Tibetan Plateau during the late Holocene: around AD 200-600, AD 800-1150, and AD 1400-1920, respectively (Yang et al., 2007). By using a set of data from a fully coupled oceanatmosphere model (FOAM), Casal et al. (2004) calculated the ice-sheet mass balance for the Tibetan Plateau for the present day, and for several different time slices of Holocene, under the insolation forcings at $3 \mathrm{kyr} \mathrm{BP}, 6 \mathrm{kyr} \mathrm{BP}, 8 \mathrm{kyr} \mathrm{BP}$ and $11 \mathrm{kyr}$ BP. Their result show that the area with positive ice-sheet mass balance expands from $11 \mathrm{kyr} \mathrm{BP}$ to $0 \mathrm{kyr} \mathrm{BP}$ (Casal et al., 2004, Fig. 11). Oven (2009) reviewed the latest Holocene glacier fluctuations in the Himalaya and Tibet, suggesting that "notable glacier advances occurred during the Late-glacial and the early Holocene, with minor advances in some regions during the mid-Holocene" and "there is abundant evidence for multiple glacial advances throughout the latter part of the Holocene". Both observation and modeling of glacier development over the Tibetan Plateau suggest that the Tibetan Plateau may have experienced a glacier fluctuation during the Holocene. There are different suggestions concerning the controlling factors on glacier expansion over Tibetan Plateau during the Holocene. Thompson et al. (2006) suggest that glacier expansion on the southern and central Tibetan Plateau is driven mainly by variation in monsoonal precipitation that is modulated by precession-driven insolation changes, while Yang et al. (2007) argued that it is the temperature change rather than precipitation change caused by variations of the south Asian summer monsoon that is the controlling factor for glacier fluctuation during the late Holocene.

In a previous model study using CLIMBER-2, Jin et al. (2005) studied the impacts of ice and snow cover over the Tibetan Plateau on Holocene climate change and the simulation results suggest that the snow and glacier environment over the Tibetan Plateau is an important factor for Holocene African-Asian monsoon retreat and an amplifier for monsoon regional climate variability. In their transient modeling experiments (Jin et al., 2005), the changes of snow and glaciers over the Tibetan Plateau was set to be simply linear increasing from $9 \mathrm{kyr}$ BP to present. However, the assumption that the snow and glaciers developing on the Tibetan Plateau were in a linear way may be unrealistic due to the complexity of snow and glacier development. Because the different scenarios of snow and glaciers developing on the Tibetan Plateau may have different effects on climate change, here, as a follow-up research of Jin et al. (2005), we conduct a series of sensitivity experiments by using CLIMBER-2 focusing on the impacts of different scenarios of snow and glaciers developing over the Tibetan Plateau on Holocene climate changes in African-Asian monsoon region and other regions.

\section{Model and experimental set-up}

\subsection{The model}

The Earth system model of intermediate complexity, CLIMBER-2, used in this study was developed in Potsdam Institute for Climate Impact Research (PIK) in Germany to perform the long-term simulations. The model consists of modules describing atmosphere, ocean, sea ice, land surface and terrestrial vegetation. The atmosphere module is a statistical-dynamical atmosphere model with a low spatial resolution of $10^{\circ}$ in latitude and $51^{\circ}$ in longitude but 
Table 1. Imposed snow and glacier scenarios in modeling experiments.

\begin{tabular}{|c|c|}
\hline Scenarios & Variations of fraction $f$ of ice cover over the Tibetan Plateau \\
\hline ICE0 & $f$ is fixed at zero for all simulations $\mathrm{AO}, \mathrm{AV}, \mathrm{AOV}$ (Grey line in Fig. 3a) \\
\hline ICE1 & $\begin{array}{l}\text { linearly increasing for the } 9 \mathrm{kyr} \text {-transient simulation, starting with } 0 \text { at } 9 \mathrm{kyr} \text { BP and ending with } 0.2 \text { at } 0 \mathrm{kyr} \text { BP } \\
\text { (Green line in Fig. 3a) }\end{array}$ \\
\hline ICE2 & $\begin{array}{l}\text { linearly increasing by } 0.05 \text { ( } 1 / 4 \text { of the maximum of fractional ice cover at } 0 \mathrm{kyr} \text { BP as in ICE1) during four } \\
\text { periods including } 7.2-8.2 \mathrm{kyr} \mathrm{BP}, 4.9-5.8 \mathrm{kyr} \mathrm{BP}, 2.4-3.32 \mathrm{kyr} \mathrm{BP} \text { and } 3.0-4.5 \mathrm{kyr} \mathrm{BP} \text {, and fixed with the val- } \\
\text { ues the previous period reached maximum during other periods, which are mainly based on result in work of } \\
\text { Lehmkuhl (1997) (Purple line in Fig. 3a) }\end{array}$ \\
\hline ICE3 & $\begin{array}{l}\text { linearly and slightly increasing in the early Holocene }(9-7 \mathrm{kyr} \mathrm{BP}) \text {, starting with } 0 \text { at } 9 \mathrm{kyr} \mathrm{BP} \text { and reaching to } \\
0.017 \text { at } 7 \mathrm{kyr} \mathrm{BP} \text {, then prescribed linearly and rapidly increasing in the mid-Holocene }(7-5 \mathrm{kyr} \mathrm{BP}) \text {, reaching to } \\
0.117 \text { at } 5 \mathrm{kyr} \mathrm{BP} \text {, finally prescribed linearly and slightly increasing between } 5 \text { and } 0 \mathrm{kyr} \mathrm{BP} \text {, ending with } 0.2 \text { at } \\
0 \mathrm{kyr} \mathrm{BP} \text {, which mimic the Nigardsbreen Glacier }\left(62^{\circ} \mathrm{N}, 7^{\circ} \mathrm{E}\right) \text { expansion during the Holocene (reference results } \\
\text { from a process-based glacier model coupled to the intermediate-complexity climate model (ECBilt), Weber et } \\
\text { al., 2003) (Red line in Fig. 3a) }\end{array}$ \\
\hline ICE4 & $\begin{array}{l}\text { linearly increasing between } 9 \mathrm{kyr} \mathrm{BP} \text { and } 6 \mathrm{kyr} \mathrm{BP} \text {, starting with } 0 \text { at } 9 \mathrm{kyr} \mathrm{BP} \text { and reaching to the maximum } \\
0.2 \text { at } 6 \mathrm{kyr} \mathrm{BP} \text {, then fixed at } 0.2 \text { between } 6 \mathrm{kyr} \mathrm{BP} \text { and } 0 \mathrm{kyr} \mathrm{BP} \text {, which mimic Abramov glacier }\left(40^{\circ} \mathrm{N}, 72^{\circ} \mathrm{E}\right) \\
\text { variation during the Holocene resulted from ECBilt (Weber et al., 2003) (Blue line in Fig. 3a) }\end{array}$ \\
\hline
\end{tabular}

explicitly resolves the large-scale circulation patterns such as subtropical jet streams, Hadley, Ferrel and polar cells, monsoon and centers of action of the Siberian high-pressure area and the Aleutian low-pressure area. It does not resolve individual synoptic weather systems but rather predicts their statistical characteristics, including the fluxes of heat, moisture, and momentum associated with ensembles of synoptic systems. The vertical structure includes a planetary boundary layer, a free troposphere (including cumulus and stratiform clouds) and a stratosphere. Radiative fluxes are computed on 16 vertical levels. In short, the model works like most coupled general circulation models (GCMs) except that synoptic-scale activity is parametrized. The ocean module is a zonally averaged model with three separate basins (Atlantic, Indian and Pacific oceans) similar to the one used by Stocker et al. (1992), including a model of sea-ice thickness, concentration, and advection, which operates with latitudinal resolution of $2.5^{\circ}$. Vertically the ocean is subdivided into 20 uneven layers. Parameterizations for its vorticity balance and Ekman transport are employed. The model of terrestrial vegetation (Brovkin et al., 2002) describe the dynamics of vegetation cover, i.e. fractional coverage of a grid cell by trees, grass, and desert (bare soil), as well as net primary productivity, leaf area index (LAI), biomass, and soil carbon pool. In CLIMBER-2, the vegetation model interacts with the atmosphere model in the way that at the end of the simulation year, output of the atmospheric model (temperature and precipitation fields) is used to simulate temporal dynamics of vegetation cover and in turn, the vegetation cover and the maximum of LAI are accounted for in calculating the surface albedo, roughness, and evapotranspiration during the following simulation year. Hence, CLIMBER-2 is able to describe changes in vegetation cover that can be interpreted as shifts in vegetation zones smaller than the spatial resolution of the model. Atmosphere and ocean interact through the surface fluxes of heat, fresh water and momentum. The model does not employ flux adjustments. The CLIMBER-2 model has been validated against present-day climate (Petoukhov et al., 2000; Ganopolski et al., 2001) and has been used successfully for a variety of paleoclimate studies (Ganopolski et al., 1998a; Claussen et al., 1999; Jin et al., 2005, 2007).

\subsection{The experimental set-up}

To mimic various scenarios of snow and glaciers developing over the Tibetan Plateau, five scenarios of snow and glacier area growth over the Tibetan Plateau were set up for the $9 \mathrm{kyr}$ transient simulation, namely ICE0, ICE1, ICE2, ICE3 and ICE4 respectively (see Table 1 for detail).

In all experiments except ICE0, the fraction of snow and glaciers in the grid cell which contain the Tibetan Plateau $\left(30^{\circ}-40^{\circ} \mathrm{N}, 40^{\circ}-90^{\circ} \mathrm{E}\right)$ in the model is prescribed starting with 0 at $9 \mathrm{kyr} \mathrm{BP}$ and ending with 0.2 at $0 \mathrm{kyr} \mathrm{BP}$, with different scenarios of variations of fraction of snow and glaciers over the Tibetan Plateau through $9 \mathrm{kyr}$ BP to $0 \mathrm{kyr} \mathrm{BP}$ (see Fig. $3 \mathrm{a}$ and Table 1 for a detail).

Three simulations using CLIMBER-2 were conducted for each scenario for snow and glacier area over the Tibetan Plateau for the Holocene. Firstly, the fully coupled atmosphere-ocean-terrestrial vegetation model (AOV) was employed for the transient simulation for the past 9000 years. Secondly, the coupled atmosphere-ocean model (AO) with vegetation cover fixed with $9 \mathrm{kyr} \mathrm{BP}$ vegetation as in the equilibrium run at $9 \mathrm{kyr} B \mathrm{P}$ was performed. Finally, the simulation $\mathrm{AV}$ was run with interactive vegetation (coupled atmosphere-vegetation model), while ocean characteristics 


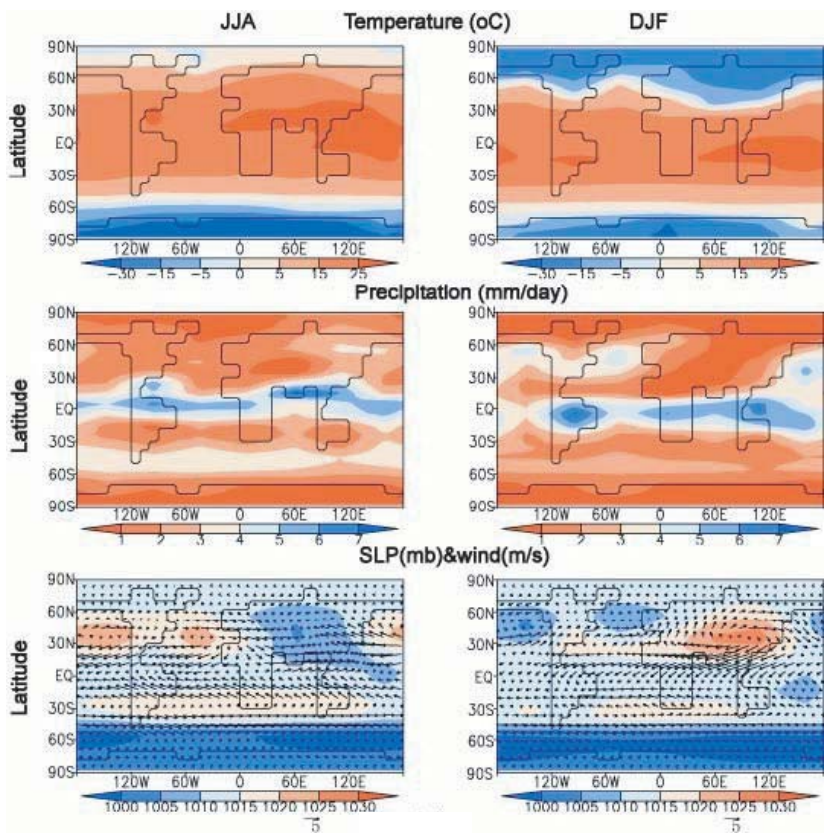

Fig. 1. Simulated climatology of CLIMBER-2 control run (0 kyr BP) for boreal summer (JJA) (left panel) and winter (DJF) (right panel) surface air temperature $\left({ }^{\circ} \mathrm{C}\right.$ ) (top level), precipitation ( $\mathrm{mm} /$ day) (middle), sea level pressure $(\mathrm{mb})$ and $850 \mathrm{hPa}$ winds $(\mathrm{m} / \mathrm{s})$ (low level).

were fixed as in the equilibrium run at $9 \mathrm{kyr} \mathrm{BP}$. The $\mathrm{AO}$ and $\mathrm{AV}$ simulations are intended to investigate interactive effects of ocean and terrestrial vegetation cover respectively. In all transient simulations (AOV, AO, AV), CLIMBER-2 was started from an equilibrium state with orbital forcing at $9 \mathrm{kyr} \mathrm{BP}$ and it was run for 9000 years until present day driven by changes in orbital parameters and by different scenarios of imposed ice forcing. The global and seasonal change of the orbital insolation is computed with the algorithm after Berger (1978). No flux corrections between the atmospheric and oceanic modules are applied in the model in any simulation. The atmospheric $\mathrm{CO}_{2}$ concentration is kept constant at $280 \mathrm{ppmv}$, and the solar constant is fixed at $1365 \mathrm{~W} \mathrm{~m}^{-2}$.

CLIMBER-2 captures most major features of the observed climatology, as can be seen in detail in work of Petoukhov et al. (2000), in which modeled and observed climatology for present day are carefully compared. Figure 1 presents the climatological surface air temperature, precipitation, sea level pressure and $850 \mathrm{hPa}$ winds for boreal summer (left panel) and winter (right panel) in the model control run (0 kyr BP). The model simulates maxima of precipitation over Western Pacific, South and Central America, following seasonal shifts of the intertropical convergence zone. Boreal summer monsoon precipitation belt is over Southern and Eastern Asia. The spatial distribution of sea level pressure (SLP) in the model by and large agrees with data in respect of the large-
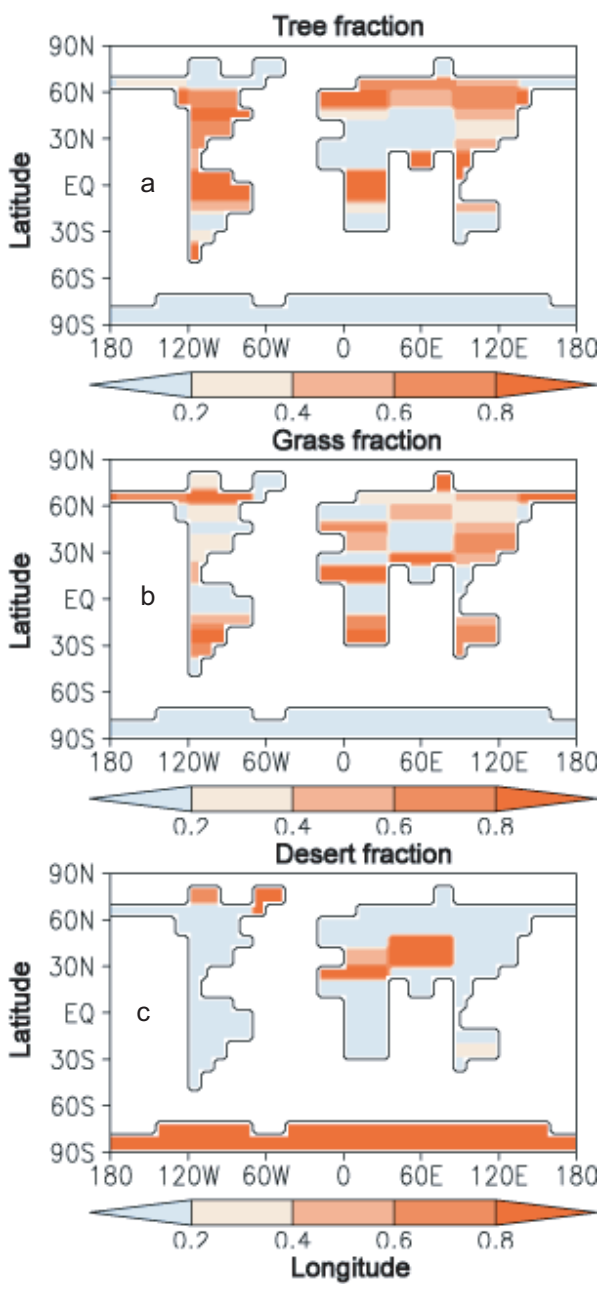

Fig. 2. Vegetation cover in CLIMBER-2. (a) Tree fraction. (b) Grass fraction. (c) Desert fraction.

scale patterns of SLP for both (June-July-August, JJA and December-January-February, DJF) seasons, including positions and absolute values of the stationary high and lowpressure systems in the subtropics and mid-latitudes. The summer Asian low pressure system is accompanied by substantial monsoon winds and heavy precipitation, especially in Southern and Eastern Asia (left panel in Fig. 1). The intensive winter Siberian high drives a strong southward Asian winter monsoon wind, which veers southeastward after crossing the equator (right panel in Fig. 1). CLIMBER-2 is able to simulate the basic global patterns of the presentday potential vegetation cover: A boreal forest belt, tropical forests (see Fig. 2a), subtropical deserts in Africa and Eurasia (Fig. 2c). Grasses occupy a significant part of high latitude regions as well as subtropical areas (Fig 2b). In midlatitudes in northern America, the model overestimates the tree fraction due to the coarse model resolution: the strong W-E gradient in precipitation is not represented by the mean values across the continent. 


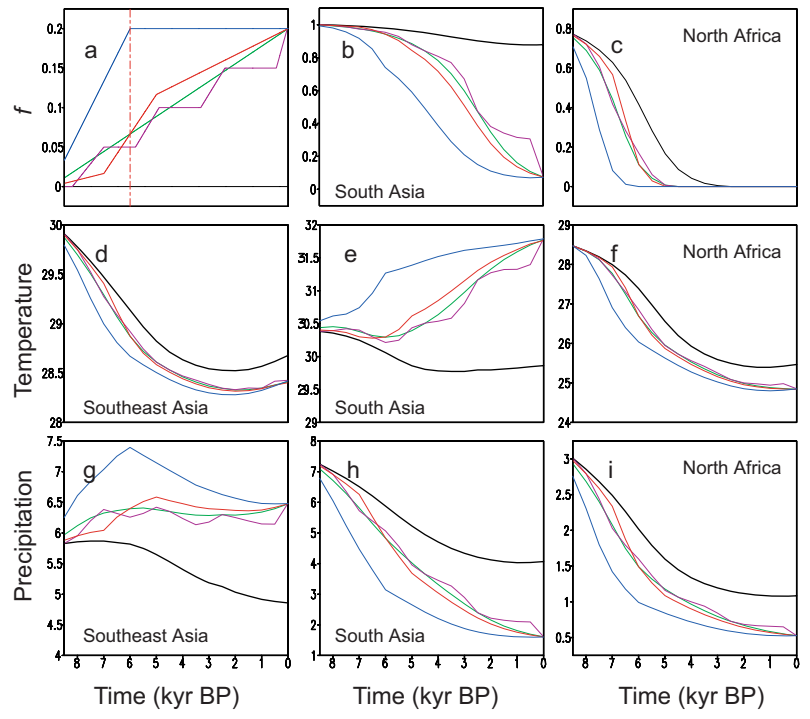

Fig. 3. Transient simulation using CLIMBER-2 for the last $9 \mathrm{kyr}$. (a) Prescribed different scenarios of snow and glaciers developing over the Tibetan Plateau in transient simulation $(f$ : fraction of snow and glaciers); (b) Simulated changes of fraction $f$ of vegetation cover in South Asia $\left(40^{\circ} \mathrm{E}-95^{\circ} \mathrm{E}, 20^{\circ} \mathrm{N}-30^{\circ} \mathrm{N}\right)$ in simulation AOV with different imposed ice scenarios in (a); (c) Same as (b) but for North Africa $\left(15^{\circ} \mathrm{W}-40^{\circ} \mathrm{E}, 20^{\circ} \mathrm{N}-30^{\circ} \mathrm{N}\right)$; (d) Same as (b) but for summer (June, July, August, JJA) near-surface air temperature in Southeast Asia $\left(95^{\circ} \mathrm{E}-145^{\circ} \mathrm{E}, 20^{\circ} \mathrm{N}-30^{\circ} \mathrm{N}\right)$; (e) Same as (d) but for South Asia $\left(40^{\circ} \mathrm{E}-95^{\circ} \mathrm{E}, 20^{\circ} \mathrm{N}-30^{\circ} \mathrm{N}\right)$; (f) Same as (e) but for North Africa; (g) Same as (f) but for JJA precipitation in Southeast Asia; (h) Same as (g) but for South Asia; (i) Same as (h) but for North Africa. Colors indicate different imposed ice scenarios ICE0 (no ice) (grey), ICE1 (green), ICE2 (purple), ICE3 (red), and ICE4 (blue) respectively in transient simulation AOV. The vertical red dash line in Fig. 3a indicates mid-Holocene (6 kyr BP) in Fig. 4.

\subsection{Temperature, precipitation and vegetation changes in the last 9 kyr}

The transient simulation in AOV revealed pronounced responses of CLIMBER-2 to changes in orbital parameters as well as the impacts of snow and glacier cover over the Tibetan Plateau (different imposed ice scenarios) on climate. Figure 3e illustrates that changes in boreal summer temperature in South Asia are quite different from that in Southeast Asia (Fig. 3d) and North Africa (Fig. 3f). Since 6 kyr BP, the summer temperature in South Asia began to increase with the fraction of snow and glacier cover increased over the Tibetan Plateau in all imposed ice scenarios (except for ICE0). The quicker increase of snow and glacier cover over the Tibetan Plateau would cause a faster increase in summer temperature in South Asia, as can be seen when compared scenario ICE4 with ICE1, ICE2, and ICE3 in Fig. 3e. In Southeast Asia and North Africa, the faster increased snow and glacier cover over the Tibetan Plateau leads to an earlier decrease in summer surface air temperature during $8 \mathrm{kyr}$ BP to $5 \mathrm{kyr} \mathrm{BP}$, but after $5 \mathrm{kyr}$ BP, even though the snow and glaciers are still growing in all ice scenarios, the summer temperature have a small change (Fig. 3d, f). The summer precipitation in Southeast Asia (Fig. 3g) increases rapidly during the early to midHolocene (9 kyr BP to $6 \mathrm{kyr}$ BP) with the gradually increased snow and glacier cover over the Tibetan Plateau, in which the faster the snow and glacier grows (scenario ICE4, blue line in Fig. 3a), the more summer precipitation increases. Since $6 \mathrm{kyr}$ BP, even though the snow and glacier are still growing (scenarios ICE1, ICE2, and ICE3), the summer precipitation in Southeast Asia no more increases or even began to decrease with the fraction of snow and glacier cover over the Tibetan Plateau was kept constant (corresponding to scenario ICE4). In North Africa, the strongest decrease in summer precipitation appears around 5.5-6.5 kyr BP in scenario ICE0 (no-ice) simulation (grey line in Fig. 3i), while in scenarios ICE1 (green), ICE2 (purple), ICE3 (red), and ICE4 (blue), it occurs around 6.5-7.5 kyr BP, 6.5-7.5 kyr BP, 6-7 kyr BP, and 7-8 kyr BP, respectively. In South Asia, including the southern part of the Tibetan Plateau, the rapid and strong reduction in summer precipitation during early to mid-Holocene is similar to that in North Africa. Compared to scenario ICE0 (no-ice), the ice scenarios (ICE1, ICE2, ICE3, and ICE4) show a pronounced increase in summer precipitation in Southeast Asia (Fig. 3g), and a decrease in South Asia (Fig. 3h) and Africa (Fig. 3i).

Figure 4 shows the global distribution of boreal summer surface air temperature and precipitation anomalies from present day (0 kyr BP) at $6 \mathrm{kyr}$ BP simulated in AOV with imposed ice scenarios ICE0 and ICE4, which is corresponded to the difference between two AOV transient simulations (with ICE0 and ICE4) at $6 \mathrm{kyr} \mathrm{BP}$ and $0 \mathrm{kyr}$ BP (see Fig. 3a, the vertical red dash line). In ICE0 (no-ice) scenarios, simulated boreal summer air temperature is up to $2^{\circ} \mathrm{C}$ higher than at present in the northern parts of Europe, Asia and North America, and summer precipitation is greater than today's in North Africa and South Asia, with maximum exceeding $1.6 \mathrm{~mm} /$ day at the center (Fig. 4, upper panel). When snow and glaciers are imposed over the Tibetan Plateau (scenario ICE4), a cooling of exceeding $2^{\circ} \mathrm{C}$ in summer surface air temperature appears over the High Asia (Fig. 4, left middle panel), and accordingly the boreal summer precipitation decreases greatly in North Africa and South Asia (Fig. 4, right middle panel) compared to scenario ICE0 (no-ice). The prominent changes of boreal summer precipitation between ICE4 and ICE0 at $6 \mathrm{kyr}$ BP are in North Africa and South Asia with a decrease at maximum by $1 \mathrm{~mm} / \mathrm{day}$, and an increase at maximum by $0.4 \mathrm{~mm} /$ day in Southeast Asia (Fig. 4, right low panel). The tendency for the pattern of rapidly increased precipitation in Southeast Asia (Fig. 3g, and Fig. 4, right low panel) and decreased in South Asia and North Africa (Fig. 4, right low panel) during the early to midHolocene reflects the tendency for the large-scale weakening African-Asian summer monsoon circulation to and a southeastward shift of the locus of monsoon rains (Fig. 4). The 

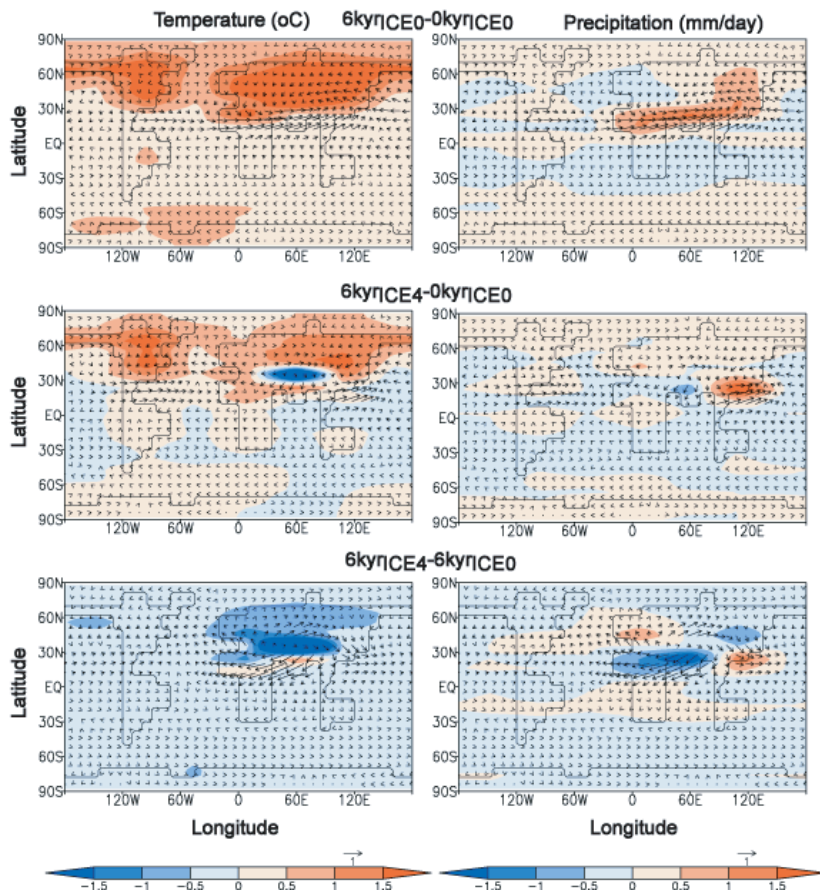

Fig. 4. Simulated global patterns of differences between midHolocene (6 kyr BP) and $0 \mathrm{kyr}$ BP for boreal summer near-surface air temperature $\left({ }^{\circ} \mathrm{C}\right)$ (left panel) and precipitation $(\mathrm{mm} /$ day) (right panel) with different imposed ice scenarios. $\left(6 \mathrm{kyr}_{\mathrm{ICE} 0}-0 \mathrm{kyr}_{\mathrm{ICE} 0}\right)$ indicates mid-Holocene (6 kyr BP) minus present day (0 kyr BP) simulations for scenario ICE0 (no-ice), $\left(6 \mathrm{kyr}_{\mathrm{ICE}} 4-0 \mathrm{kyr}\right.$ ICE0 $)$ indicates $6 \mathrm{kyr} \mathrm{BP}$ simulation for scenarios ICE4 minus $0 \mathrm{kyrBP}$ simulation for scenario ICE0 and $\left(6 \mathrm{kyr}_{\text {ICE} 4}-6 \mathrm{kyr}_{\text {ICE0 }}\right)$ indicates $6 \mathrm{kyr}$ BP simulation for scenarios ICE4 minus $6 \mathrm{kyr}$ BP simulation for scenarios ICE0. Vector arrows indicate simulations of $850 \mathrm{hPa}$ wind field $(\mathrm{m} / \mathrm{s})$ differences between $6 \mathrm{kyr}$ BP and $0 \mathrm{kyr}$ BP for corresponding imposed ice scenarios.

weakening and shift of the monsoon is a result of the adjustment of the atmospheric circulation to the changes in thermal contrast between the African and Eurasian continent and the Pacific and Indian Oceans during the boreal summer due to the gradually weakened seasonal cycle of solar insolation in the northern hemisphere. The weakening of the Asian summer monsoon circulation is supported by the paleoclimate records (Morrill et al., 2003; Tang et al., 2000).

Compared to the changes in near-surface air temperature and precipitation, the fraction $f$ of vegetation cover (trees plus grasses) changed differently. Fig. 3b, c shows responses of the changes in the fraction $f$ of vegetation cover to the different scenarios of gradually increased snow and glaciers over the Tibetan Plateau in South Asia and North Africa. In North Africa (Fig. 3c), the vegetation cover decreases earlier and more rapidly than that in South Asia (Fig. 3b) in all imposed ice scenarios. Complete desertification in North Africa appears around $3.5 \mathrm{kyr}$ BP with no-ice imposed over the Tibetan Plateau (scenario ICE0), and by $5.0 \mathrm{kyr}$ BP (scenarios
ICE1, ICE2, ICE3), and 6 kyr BP (scenario ICE4) respectively (Fig. 3c), showing a strong effect of snow and glacier cover over the Tibetan Plateau on North African vegetation development. In South Asia, the response of the changes in vegetation cover to the gradually increased snow and glaciers over the Tibetan Plateau lags behind North Africa a few thousand years (the fraction of vegetation cover in South Asia reduces only $10 \%(\Delta f \sim-0.1)$ for the first $5 \mathrm{kyr}$ for scenarios of ICE1, ICE2, and ICE3) (Fig. 3b), while the fraction of vegetation cover in North Africa reached almost zero at $5 \mathrm{kyr}$ BP (Fig. 3c). The snow and glacier influence on changes of vegetation cover in South Asia began after $5 \mathrm{kyr} \mathrm{BP}$, with a rather rapidly decrease in vegetation cover from 3.5 to $2 \mathrm{kyr}$ BP $(\Delta f \sim-0.35)$ in scenarios of ICE1, ICE2, and ICE3. In scenario ICE4, even though the snow and glacier cover would not increase any more after 6 kyr BP (Fig. 3a, blue line), its influence last for the rest of the Holocene vegetation evolution compared with scenario ICE0 (Fig. 3b). The simulated fraction of vegetation cover in North Africa are generally in agreement with proxy records of changes in vegetation cover evidenced from ocean temperature and terrigenous dust in marine sediment records off western Africa (deMenocal et al., 2000). The percentage of terrigenous dust contents indicates a dramatic increase in the amount of dust that relates directly to the changes in vegetation as the Sahara expanded across North Africa during 5.7 kyr BP to 5.0 kyr BP (deMenocal et al., 2000).

\subsection{Effects of imposed ice-albedo change on North African and South Asian climate}

In order to investigate the synergy between imposed icealbedo change over Tibetan Plateau and the vegetation feedbacks, in addition to the fully coupled experiments (AOV) discussed above, we performed two sets of transient simulations with fixed vegetation cover $(\mathrm{AO})$ and fixed ocean characteristics (AV). Figure 5 shows simulated results in North Africa for the last 9000 years from simulations AO, AV, AOV with no-ice scenario ICE0, and with ice scenarios ICE1 and ICE4. A rapid decrease in the near-surface air temperature during the mid-Holocene in ICE4 scenario occurs about 1 kyr earlier than in scenario ICE1, and 2 kyr earlier than in scenario ICE0 both in simulations AV and AOV (Fig. 5a, b, c). Similar behavior is seen in changes in summer precipitation (Fig. 5d, e, f) and vegetation cover in North Africa (Fig. 5g, h, i). Results of experiments AV and AOV for North Africa show a similar response of CLIMBER-2 to changes in orbital parameters and ice-imposed forcing over the Tibetan Plateau while results of experiment AO show a less climate variations in all ice-imposed scenarios. In simulation AO (without vegetation interaction and no ice imposed) (Fig. 5a, long dash line), the summer near-surface air temperature decreases slowly and smoothly during the early to middle Holocene due to the slow decrease of surface absorbed solar radiation (Fig. 6a, long dash line) and of the 

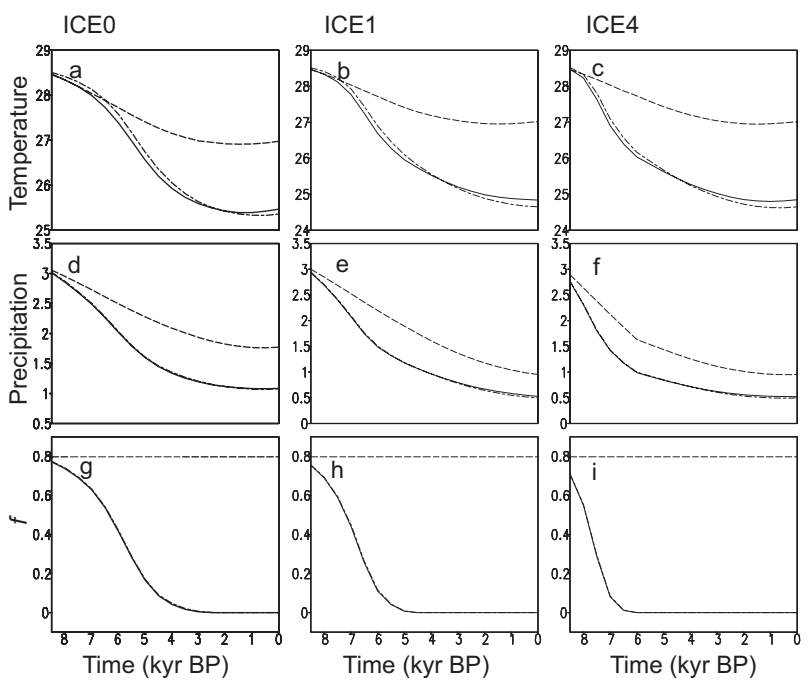

Fig. 5. Changes in summer (June, July, August, JJA) near-surface air temperature $\left({ }^{\circ} \mathrm{C}\right)(\mathbf{a}, \mathbf{b}, \mathbf{c})$, precipitation $(\mathrm{mm} /$ day $)(\mathbf{d}, \mathbf{e}, \mathbf{f})$, and vegetation cover $(\%)(\mathbf{g}, \mathbf{h}, \mathbf{i})$ in North Africa $\left(15^{\circ} \mathrm{W}-40^{\circ} \mathrm{E}, 20^{\circ} \mathrm{N}-\right.$ $30^{\circ} \mathrm{N}$ ) for the last $9 \mathrm{kyr}$ in simulations $\mathrm{AO}$ (long dash line), $\mathrm{AV}$ (long and short dash lines), and AOV (solid line) with imposed ice scenarios ICE0 (no-ice) (a, d, g), ICE1 (b, e, h), and ICE4 (c, f, i).
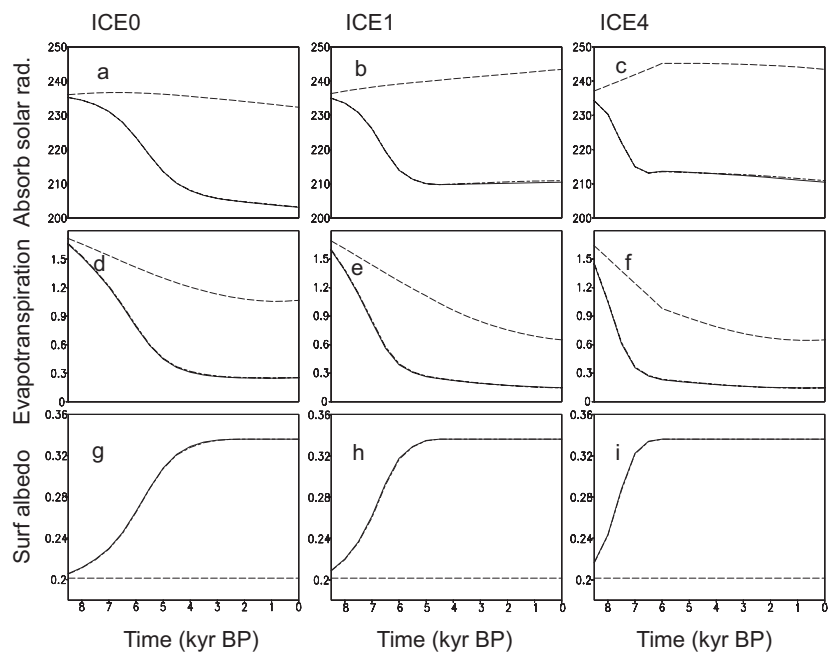

Fig. 6. Changes in summer (JJA) surface absorbed solar radiation $\left(\mathrm{W} / \mathrm{m}^{2}\right)(\mathbf{a}, \mathbf{b}, \mathbf{c})$, evapotranspiration ( $\mathrm{mm} /$ day) $(\mathbf{d}, \mathbf{e}, \mathbf{f})$, and surface albedo $(\mathbf{g}, \mathbf{h}, \mathbf{i})$ in North Africa $\left(15^{\circ} \mathrm{W}-40^{\circ} \mathrm{E}, 20^{\circ} \mathrm{N}-30^{\circ} \mathrm{N}\right)$ for the last $9 \mathrm{kyr}$ in simulations $\mathrm{AO}$ (long dash line), AV (long and short dash lines), and AOV (solid line) with imposed ice scenarios ICE0 (no-ice) $(\mathbf{a}, \mathbf{d}, \mathbf{g})$, ICE1 $(\mathbf{b}, \mathbf{e}, \mathbf{h})$, and ICE4 $(\mathbf{c}, \mathbf{f}, \mathbf{i})$.

latent heat flux (evapotranspiration) (Fig. 6d). But in simulations $\mathrm{AV}$ and $\mathrm{AOV}$, the summer near-surface air temperature and precipitation change more strongly than in simulation AO in North Africa during 7-5 kyr BP (Fig. 5). A parallel rapid decrease in surface absorbed solar radiation (Fig. 6a), latent heat flux (evapotranspiration) (Fig. 6d) and the rapid

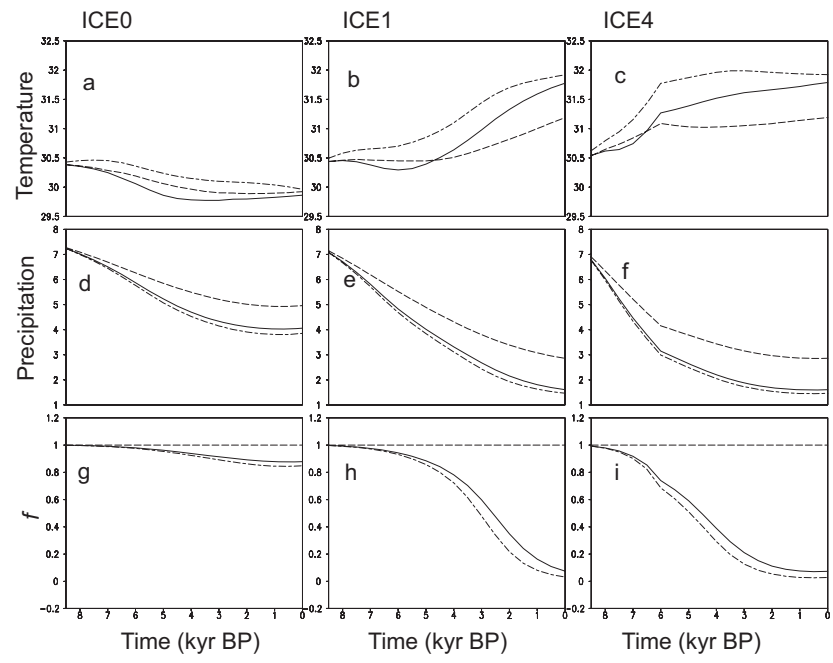

Fig. 7. Same as Fig. 5 except for region in South Asia $\left(40^{\circ} \mathrm{E}-95^{\circ} \mathrm{E}\right.$, $\left.20^{\circ} \mathrm{N}-30^{\circ} \mathrm{N}\right)$.

increase in surface albedo (Fig. $6 \mathrm{~g}$ ) are caused by a strong positive feedback between subtropical vegetation and precipitation. This feedback emerges from an interaction between high albedo of Saharan sand deserts and atmospheric circulation as hypothesized by Charney et al. (1975) and from subsequent changes in the hydrological cycle (Claussen, 1997, 1998). If the snow and glaciers over the Tibetan Plateau (scenarios ICE1, ICE4) are imposed with simulations AV and AOV, the abrupt regional changes in summer precipitation (Fig. 5e, f) and vegetation cover (Fig. 5h, i) occur earlier than in no-ice (ICE0) experiments. The faster the ice cover increases over the Tibetan Plateau (Fig. 3a), the earlier and more rapidly the decrease in summer precipitation and vegetation cover in North Africa appear (Fig. 5). It tends to be that the effect of ice over the Tibetan Plateau "accelerates" the abrupt changes in summer precipitation and vegetation cover in North Africa, while the ocean (AO experiment) plays only a minor role in North African climate change during the Holocene, as a previous modeling study in work of Claussen et al. (1999).

In South Asia, whereas the summer precipitation decreases rapidly during the early to middle Holocene (Fig. 7d, e, f), which is similar to that in North Africa, the summer near-surface air temperature (Fig. 7b, c) and vegetation cover (Fig. 7h, i) have a different evolution compared to that in North Africa (Fig. 5). With a linear increase in snow and glacier cover over the Tibetan Plateau in scenario ICE1 (Fig. 3), the summer near-surface air temperature in South Asia began to increase after around $6 \mathrm{kyr} \mathrm{BP}$ in simulations AO, AV, AOV (Fig. 7b), while in North Africa, it still decreases after 6 kyr BP (Fig. 5b). In scenario ICE4 (Fig. 7c), the summer near-surface air temperature in South Asia began to increase almost along with the increase of snow and glacier cover over the Tibetan Plateau at the early Holocene. 


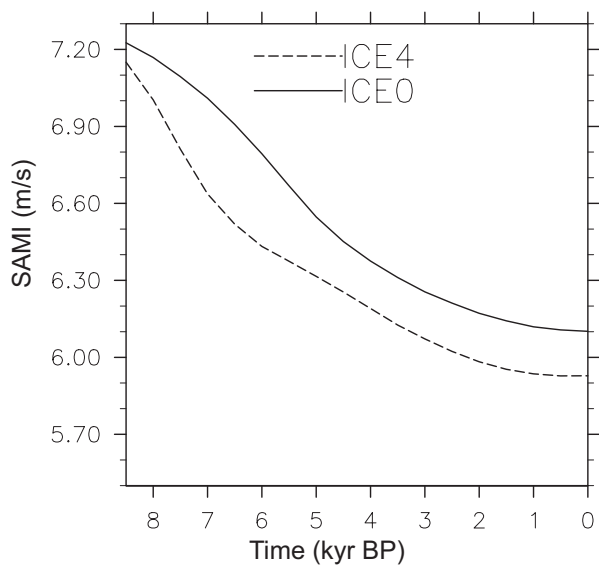

Fig. 8. Changes in South Asian summer monsoon index (SAMI) $(\mathrm{m} / \mathrm{s})$ in transient simulation AOV for two scenarios (ICE0, ICE4). The SAMI here is defined as the difference of averaged westerlies over $850 \mathrm{hPa}$ and $200 \mathrm{hPa}$ in South Asian monsoon area $\left(40^{\circ} \mathrm{E}-95^{\circ} \mathrm{E}, 0^{\circ}-20^{\circ} \mathrm{N}\right)$, which is referenced in Webster-Yang Index (Webster and Yang, 1992) and modified according to spatial resolution of CLIMBER-2.

The rapidly increased summer near-surface air temperature in South Asia is closely related to the rapid decreases in summer precipitation (Fig. 7e, f) and vegetation cover (Fig. 7h, i) in this region. Figure $7 \mathrm{e}, \mathrm{f}$ shows that the summer precipitation in South Asia decreases stronger in the experiments with imposed snow and glacier cover over the Tibetan Plateau (scenarios ICE1, ICE4) compared to that in no ice scenario (ICE0) (Fig. 7d) in AO, AV, and AOV simulations. Similarly, it is shown that the faster increase in snow and glacier cover over the Tibetan Plateau (scenarios ICE1, ICE4) would cause an earlier (about 1000-2000 years) and more rapid decrease in vegetation cover in South Asia (Fig. 7h, i) compared to that in no-ice scenario (ICE0) (Fig. 7g). The rapid decrease in summer precipitation in South Asia during the early to middle Holocene (9-6 kyr BP) in ice imposed scenarios (ICE1, ICE4) (Fig. 7e, f) is closely related to the weakening of the South Asian summer monsoon (Fig. 8). It shows that the South Asian summer monsoon strength, which is indicated by the South Asian summer monsoon index (SAMI) as referenced in Webster and Yang (1992), reduces much more rapidly during 9-6 kyr BP in ICE4 scenario than in ICE0 scenario (Fig. 8). But the vegetation cover changes slower (Fig. $7 \mathrm{~g}, \mathrm{~h}, \mathrm{i}$ ) compared to that in North Africa (Fig. 5g, h, i), and the surface albedo remains relatively low (Fig. 9g, h, i) compared to that in North Africa (Fig. 6g, h, i) during 9-6 kyr BP. These are corresponded to a smooth decrease of absorption of solar radiation in this region before $5 \mathrm{kyr}$ BP in ICE0 experiment (Fig. 9a), but an increase of absorption of solar radiation in ICE1 and ICE4 experiments, as can be also compared to summer near-surface air temperature changes during the early to middle Holocene in this region (Fig. 7a, $b, c)$. The increased summer near-surface air temperature in

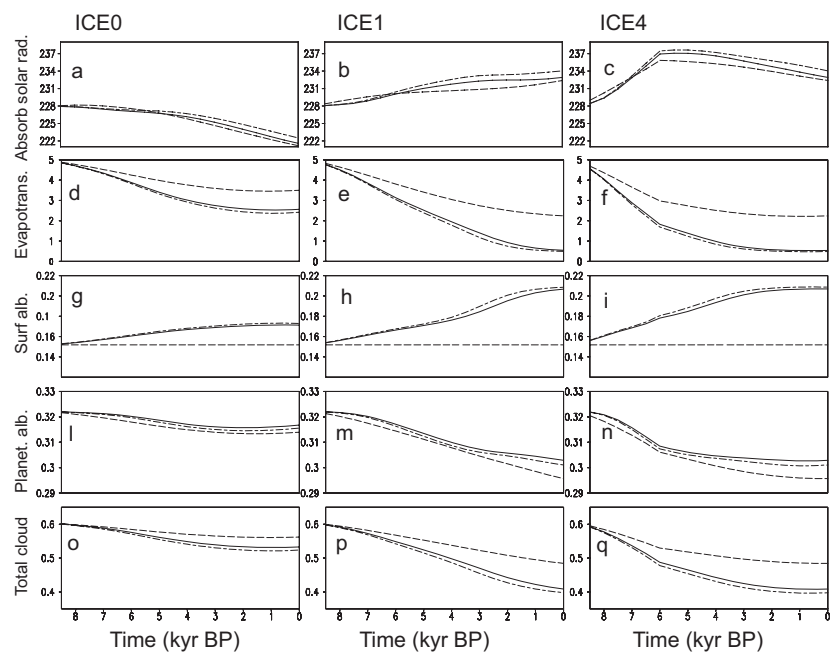

Fig. 9. Simulated changes in summer (JJA) (a) surface absorbed solar radiation $(\mathbf{a}, \mathbf{b}, \mathbf{c})$, evaporation $(\mathbf{d}, \mathbf{e}, \mathbf{f})$, surface albedo $(\mathbf{g}, \mathbf{h}$, i), planetary albedo $(\mathbf{l}, \mathbf{m}, \mathbf{n})$, and total clouds in South Asia $\left(\left(40^{\circ} \mathrm{E}-\right.\right.$ $95^{\circ} \mathrm{E}, 20^{\circ} \mathrm{N}-30^{\circ} \mathrm{N}$ ) for the last $9 \mathrm{kyr}$ in simulations $\mathrm{AO}$ (long dash line), AV (long and short dash lines), and AOV (solid line) with imposed ice scenarios ICE0 (no-ice) $(\mathbf{a}, \mathbf{d}, \mathbf{g})$, ICE1 (b, e, h), and ICE4 $(\mathbf{c}, \mathbf{f}, \mathbf{i})$.

experiments with imposed ice scenarios (ICE1, ICE4) corresponds to the increases in absorption of solar radiation (Fig. 9b, c). Although the surface albedo increases (Fig. 9h, i), the planetary albedo decrease with time (Fig. 9m, n) due to a strong reduction of cloud cover (Fig. 9p, q), which is, in turn, a result of weakening of moisture convergency due to weakening of summer monsoon.

In boreal summer, the latent heat released from North Indian Ocean sea surface transports to air over the South Asian continent via Indian monsoon circulation. Figure 10 shows the simulated changes in sea surface temperature (SST) between $9 \mathrm{kyr} \mathrm{BP}$ and $0 \mathrm{kyr} \mathrm{BP}$ in North Indian Ocean $\left(40^{\circ} \mathrm{E}-\right.$ $95^{\circ} \mathrm{E}, 0^{\circ} \mathrm{N}-20^{\circ} \mathrm{N}$ ) in experiment $\mathrm{AOV}$ for no ice scenario (ICE0). Although a gradually increased SST (Fig. 10c) is favor to increase the latent heat flux to air over the South Asian continent, the increase of evaporation over the ocean and a stronger moisture transport from ocean also increase the cloudiness that may compensate release of latent heat over sea surface. It is suggested from our modeling experiment that the rapid decrease in precipitation and vegetation cover after $5 \mathrm{kyr}$ BP (Fig. 7e, h) could reduce the planetary albedo, which increases the absorbtion of solar radiation and hence increases the summer air temperature in this region. Small changes in SST (Fig. 10) in neighboring North Indian Ocean (by $0.3^{\circ} \mathrm{C}$ between $9 \mathrm{kyr} \mathrm{BP}$ and $0 \mathrm{kyr} \mathrm{BP}$ ) can only play a very minor role in the South Asian continental warming. 

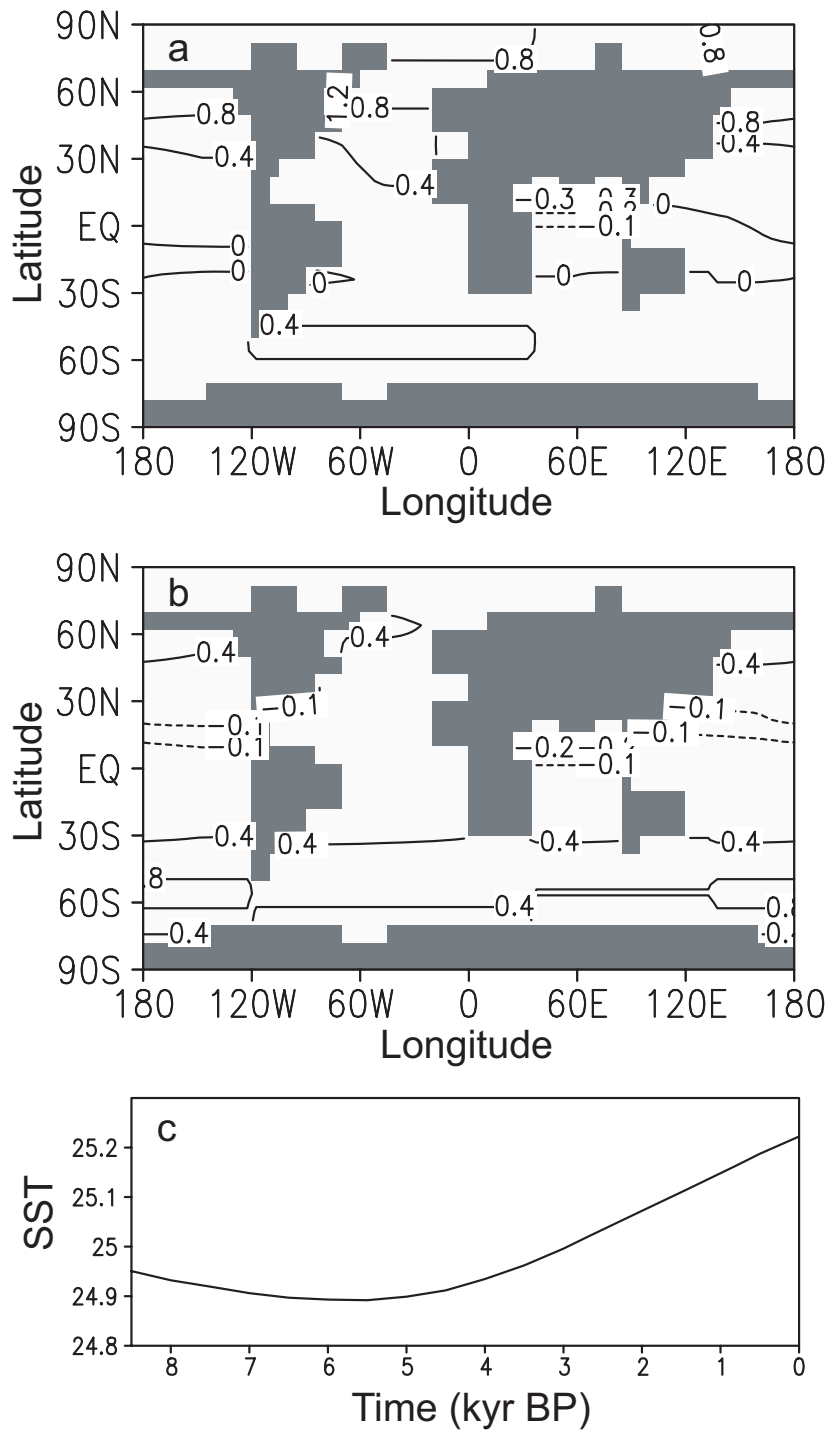

Fig. 10. Differences in sea surface temperature (SST) between $9 \mathrm{kyr} \mathrm{BP}$ and $0 \mathrm{kyr} \mathrm{BP}$ in experiment AOV with ICE0 (no-ice scenario) in boreal summer (a) and winter (b); (c) Changes in boreal summer SST $\left({ }^{\circ} \mathrm{C}\right)$ in North Indian Ocean $\left(40^{\circ} \mathrm{E}-95^{\circ} \mathrm{E}, 0^{\circ} \mathrm{N}-\right.$ $20^{\circ} \mathrm{N}$ ) for the last $9 \mathrm{kyr}$ in transient simulation $\mathrm{AOV}$ with scenario ICE0.

\subsection{Comparison with paleoclimate records and within different ice scenarios}

Climate proxy records have revealed a wetter climate in North African and Asian monsoon regions in the early Holocene (Hoelzmann et al., 1998; Jolly et al., 1998; Kohfeld and Harrison, 2000; Yu et al., 1998, 2001). After 8 kyr BP boreal summer insolation gradually declined and it appears that monsoon dynamics became more sensitive to other factors, such as transient climatic perturbations and terrestrial feedbacks involving vegetation. In a previous model- ing study by using CLIMBER-2, Claussen et al. (1999) simulated that the decrease of the North African monsoon from early Holocene toward the present is consistent with the generally decreasing wetter conditions in North Africa, in which the simulated rapidly collapsed monsoon within several centuries during the end of the middle Holocene is supported by the ocean temperature and terrigenous dust in marine sediment records off western Africa (deMenocal et al., 2000). The abrupt African climate response was attributed to the highly non-linear feedbacks linking progressive decreases in regional precipitation, vegetation cover loss, and increasing surface albedo (Claussen et al., 1999). This simulation is similar to our simulation AOV in ICE0 (no-ice) scenario (Fig. 3c). The sensitivity experiments of simulation AOV in ice imposed scenarios (ICE1, ICE2, ICE3, and ICE4) show an earlier and more abrupt termination of the African humid period during mid-Holocene (see Fig. 3c, i and Fig. 5e, f, h, i) for changes in vegetation cover and summer precipitation), where the effect of imposed ice resembles the cold event at about $8 \mathrm{kyr}$ BP when a reduction in rainfall over regions such as North Africa caused a period of centennial-scale aridity (Gasse and Van Campo, 1994; Alley et al., 1997).

The drought conditions (gradually increased summer nearsurface air temperature and rapidly decreased summer precipitation and vegetation cover in South Asia (rapid changes after 5 kyr BP in scenario ICE1 (Fig. 7b, e, h), and 10002000 years earlier in scenario ICE4 (Fig. 7c, f, i) are consistent with paleoclimate evidences of climatic and environmental desiccation during 8-4 kyr BP. Record in the Lake Lunkaransar (within the Thar desert, South Asia) shows that a major environmental change led to an abrupt fall in the lake level around $6.4 \mathrm{kyr} \mathrm{BP}$ and the lake was completely dry by around $5.5 \mathrm{kyr}$ BP (Enzel et al., 1999). In the Ganga plain where is being controlled largely by climatic variability associated with the monsoon rains, the conversion of river channels into ponds between $8 \mathrm{kyr}$ BP and $6 \mathrm{kyr}$ BP, with fluvial activity in the region ceased sometime between $7 \mathrm{kyr}$ BP and 5 kyr BP (Srivastava et al., 2003). The arid phase might have intensified around 4-3.5 kyr BP as has been observed in the terrestrial record in the Himalayas (Phadtare, 2000; Chauhan and Sharma, 1996), western peninsula (Cratini et al., 1994), and northwestern India (Singh et al., 1990). The Indian summer monsoon, as indicated by the percentages of fossil shells of planktic foraminifer Globogerina bulloides in an upwelling record from the Arabian Sea (Gupta et al., 2005), shows a gradual weakening over the past $8 \mathrm{kyr}$ with a more or less stable dry phase beginning about $5 \mathrm{kyr}$ BP that coincides with the onset of an arid phase in Indian (Sharma et al., 2004) and termination of the Indus Valley civilization (Staubwasser et al., 2003; Gupta, 2004). As in North Africa, the effect of snow and glaciers over the Tibetan Plateau "accelerate" the decreases in summer precipitation and vegetation cover and an increase in summer near-surface air temperature in South Asia, as can be compared from experiments in scenarios ICE1 and ICE4 to ICE0 (Fig. 7, Fig. 3e, h). 
The faster the ice cover increases over the Tibetan Plateau, the earlier and more rapidly the decrease in vegetation cover appears (Fig. 7h, i). Comparatively, the simulated climate change in South Asia (onset of dry conditions) during midHolocene in ICE1, ICE2, and ICE3 scenarios is closer to proxy data, in which the temporal evolution patterns of the three scenarios are similar (Fig. 3e). In ICE0 scenario, only small climate changes (gradually decreased changes in summer near-surface air temperature, precipitation and vegetation cover appear (Fig. 7a, d, g). In ICE4 scenario, the effect of imposed ice seems to be over stronger to result in a much earlier rapid climate change (Fig. 7c, f, i) than that in ICE1, ICE2, and ICE3 which is less consistent to paleoclimatic records.

\section{Summary and concluding remarks}

Using the Earth system model of intermediate complexity, CLIMBER-2, the Holocene climate changes were simulated forced by variations of Earth's orbital parameters and different scenarios of snow and glaciers developing over the Tibetan Plateau. The simulations show an additional decrease in boreal summer temperature in mid-Holocene (6 kyr BP) when snow and glaciers are imposed over the Tibetan Plateau, especially in the northern parts of Europe, Asia, and North America. An increase in snow and glaciers over the Tibetan Plateau for the last 9000 years would lead to an earlier and more rapidly climate change in African-Asian monsoon region as well as the changes in summer temperature in South Asia and summer precipitation in Southeast Asia. The faster the snow and glaciers increase, the earlier the rapid decrease in boreal summer temperature and precipitation as well as vegetation cover in North Africa. However, the faster increase in snow and glaciers over the Tibetan Plateau would cause an increase in summer near-surface air temperature in South Asia. The rapid decrease in vegetation in South Asia was lagged behind North Africa about 1500 to 2000 years.

The model results suggest that the development of snow and ice cover over the Tibetan Plateau represents an additional important climate feedback, which amplify orbital forcing and produces a significant synergy with the positive vegetation feedback. In North Africa, an enhanced snow and glacier fraction over the Tibetan Plateau tends to cause an earlier and more rapid decrease in summer near-surface air temperature, precipitation and vegetation cover during the early to mid-Holocene, with a parallel decrease in surface absorbed solar radiation, latent heat flux (evapotranspiration) and the rapid increase in surface albedo, which are caused by a strong positive feedback between subtropical vegetation and precipitation that emerges from an interaction between high albedo of Saharan sand deserts and atmospheric circulation and from subsequent changes in the hydrological cycle. In South Asia, the summer near-surface air temperature and vegetation cover have a different evolution during the Holocene compared to that in North Africa. The summer near-surface air temperature in South Asia began to increase almost along with the increase of snow and glacier cover over the Tibetan Plateau at the early Holocene. The rapidly increased summer near-surface air temperature in South Asia is closely related to the rapid decreases in summer precipitation and vegetation cover in this region. The summer precipitation in South Asia decreases stronger in the experiments with imposed snow and glacier cover over the Tibetan Plateau than that in no ice scenario simulations during the early to mid-Holocene. Similarly, an earlier (about 1000-2000 years) and more rapid decrease in vegetation cover in South Asia appear in the experiments with the faster increase in snow and glacier cover over the Tibetan Plateau. The rapid decrease in summer precipitation in South Asia during the early to middle Holocene (9-6 kyr BP) in ice imposed scenarios is closely related to the weakening of the South Asian summer monsoon. But the vegetation cover changes slower and the surface albedo remains relatively low compared to that in North Africa during 9-6 kyr BP. These are corresponded to a smooth decrease of absorption of solar radiation in this region before $5 \mathrm{kyr}$ BP with no-ice imposed over the Tibetan Plateau, but an increase of absorption of solar radiation in ice imposed over the Tibetan Plateau. The increased summer near-surface air temperature in experiments with imposed ice scenarios corresponds to the increases in absorption of solar radiation. Although the surface albedo increases, the planetary albedo decrease with time due to a strong reduction of cloud cover, which is, in turn, a result of weakening of moisture convergency due to weakening of summer monsoon.

Although our modeling experiments have focused on cooling effect induced by different scenarios of snow and glaciers developing over the Tibetan Plateau on Holocene climate change in African and Asian summer monsoon regions, it must be emphasized that due to a very coarse spatial resolution of CLIMBER-2 model $\left(10^{\circ}\right.$ in latitude and $51^{\circ}$ in longitude in atmosphere module), the simulated changes in the intensity of individual monsoon systems should be treated with caution and only as qualitative. Such as in the African summer monsoon region, the simulated $850 \mathrm{hPa}$ winds for boreal summer (JJA) at present day (0 kyr BP, ICE0) seems to "underestimate" the intensity of African summer southwest winds (Fig. 1, left panel in low level), which probably results in an uncertainty of summer precipitation in this region. To capture accurately effects of land surface changes on climate, a more detailed feedback analysis with additional experiments is warranted and more sensitivity experiments with high resolution models are necessary.

Acknowledgements. This study was supported by the National Natural Science Foundation of China (NSFC) (Grant No. 40571169), the NSFC Innovation Team Project (Grant No. 40721061) and the 111 Project (Grant No. B06026). Bette Otto-Bliesner of National Center for Atmospheric Research (NCAR) is thanked for her helpful reviewing and English improvement of the manuscript. 
Two anonymous reviewers of the paper during the Interactive Discussion phase are thanked for their constructive suggestions and comments.

Edited by: P. Braconnot

\section{References}

Alley, R. B., Mayewski, P. A., Sowers, T., Stuiver, M., Tayor, K. C., and Clark, P. U.: Holocene climate instability: A prominent, widespread event 8200 years ago, Geology, 25, 483-486, 1997.

An, Z. S., Porter, S. C., Kutzbach, J. E., Wu, X., Wang, S., Liu, X. D., Li, X. Q., and Zhou, W. J.: Asynchronous Holocene optimum of the East Asian monsoon, Quaternary Sci. Rev., 19, 743-762, 2000.

Berger, A. L.: Long-term variations of daily insolation and quaternary climatic changes, J. Atmos. Sci., 35, 2362-2367, 1978.

Brovkin, V., Bendtsen, J., Claussen, M., Ganopolski, A., Kubatzki, C., Petoukhov, V., and Andreev, A.: Carbon cycle, vegetation, and climate dynamics in the Holocene, Experiments with the CLIMBER-2 model, Global Biogeochem. Cycles, 16(4), 1139, doi:10.1029/2001GB001662, 2002.

Casal, T. G. D., Kutzbach, J. E., and Thompson, L. G.: Present and past ice-sheet mass balance simulations for Greenland and the Tibetan Plateau, Clim. Dyn., 23, 407-425, 2004.

Chauhan, O. S.: Past 20 000-year history of Himalayan aridity: Evidence from oxygen isotope records in the Bay of Bengal, Current Science, 84(1), 90-93, 2003.

Chauhan, M. S. and Sharma, C.: Pollen analysis of mid-Holocene sediments from Kumaon Himalaya, Proc. Symposium NW Himalaya and Foredeep Geol. Surv. India Spec. Publ., 257-269, 1996.

Christner, B. C., Mosley-Thompson, E., Thompson, L.G., and Reeve, J. N.: Bacterial recovery from ancient glacier ice, Environ. Microbiol., 5, 433-436, 2003.

Claussen, M., Kubatzki, C., Brovkin, V., Ganopolski, A., Hoelzmann, P., and Pachur, H.: Simulation of an abrupt change in Saharan vegetation in the mid-Holocene, Geophys. Res. Lett., 24(14), 2037-2040, 1999.

Claussen, M.: Modeling biogeophysical feedback in the African and Indian Monsoon region, Clim. Dyn., 13, 247-257, 1997.

Claussen, M. and Gayler, V.: The greening of Sahara during the mid-Holocene: Results of an interactive atmospheric-biome model, Global Ecol. Biogeogr. Lett., 6, 369-377, 1997.

COHMAP Members: Climatic changes of the 18000 years: Observations and model simulation, Science, 241, 1043-1052, 1988.

Cratini, C., Bentaleb, I., Fontugne, M., Morzadec-Kerpourn, M. T., Pascal, J. P. and Tissot, C.: A less humid climate since ca. 33500 yr B.P. from marine cores off Karwar, western India, Palaeogeogr., Palaeoclimatol., Palaeoecol., 109, 371-384, 1994.

deMenocal, P., Ortiz, J., Guilderson, T., and Sarnthein, M.: Coherent high- and low-latitude climate variability during the Holocene warm period, Science, 288, 2198-2202, 2000.

Enzel, Y., Ely, L. L., Mishra, S., Ramesh, R., Amit, R., Lazar, B., Rajuguru, S. N., Baker, V. R., and Sandler, A.: High-resolution Holocene environmental changes in the Thar Desert, northwestern India, Science, 284, 125-128, 1999.

Foley, J. A., Kutzbach, J. E., Coe, M. T., and Levis, S.: Feedbacks between climate and boreal forests during the Holocene epoch,
Nature, 371, 52-54, 1994.

Ganopolski, A., Rahmstorf, S., Petoukhov, V., and Claussen, M.: Simulation of modern and glacial climates with a coupled model of intermediate complexity, Nature, 391, 351-356, 1998a.

Ganopolski, A., Kubatzki, C., Claussen, M., Brovkin, V., and Petoukhov, V.: The influence of vegetation-atmosphere-ocean interaction on climate during the mid-Holocene, Science, 280, 1916-1919, 1998b.

Ganopolski, A., Petoukhov, V., Brovkin, V., Claussen, M., Eliseev, A., Kubatzki, C., and Rahmstorf, S.: CLIMBER-2: A climate system model of intermediate complexity. part II: Model sensitivity, Clim. Dyn., 17, 735-751, 2001.

Gasse, F. and Van Campo, E.: Abrupt post-glacial climate events in West Asia and North Africa monsoon domains, Earth Planet. Sc. Lett., 126, 435-456, 1994.

Gupta, A. K.: Origin of agriculture and domestication of plants and animals linked to early Holocene climate amelioration, Curr. Sci., 87, 54-59, 2004.

Gupta, A. K. and Anderson, D. M.: Mysteries of the Indian Ocean monsoon system, J. Geo. Soc. India, 65, 54-60, 2005.

Gupta, A. K., Anderson, D. M., and Overpeck, J. T.: Abrupt changes in the Asian southwest monsoon during the Holocene and their links to the North Atlantic Ocean, Nature, 421, 354357, 2003.

Gupta, A. K., Das M., and Anderson, D. M.: Solar influence on the Indian summer monsoon during the Holocene, Geophys. Res. Lett., 32, L17703, doi:10.1029/2005GL022685, 2005.

Hoelzmann, P., Jolly, D., Harrison, S. P., Laarif, F., Bonnefille, R., and Pachur, H. J.: Mid-Holocene land-surface conditions in northern Africa and the Arabian Peninsula: A data set for the analysis of biogeophysical feedbacks in the climate system, Global Biogeochem. Cycles, 12, 35-52, 1998.

Huang, C. C.: Environmental changes, Beijing, Science Press, 121145, 1998 (in Chinese).

Jin, L., Ganopolski, A., Chen, F., Claussen, M., and Wang, H.: Impacts of snow and glaciers over Tibetan Plateau on Holocene climate change: Sensitivity experiments with a coupled model of intermediate complexity, Geophys. Res. Lett., 32, L17709, doi:10.1029/2005GL023202, 2005.

Jin, L., Chen, F., Ganopolski, A., and Claussen, M.: Response of East Asian climate to Dansgaard/Oeschger and Heinrich events in a coupled model of intermediate complexity, J. Geophys. Res., 112, D06117, doi:10.1029/2006JD007316, 2007.

Jolly, D., Pretice, I. C., Bonnefille, R., Aziz Ballouche, A., Bengo, M., Brenac, P., Buchet, G., Burney, D., Cazet, J.-P., Cheddadi, R., Edorh, T., Elenga, H., Elmoutaki, S., Guiot, J., Laarif, F., Lamb, H., Lezine, A.-M. Maley, J., Mbenza, M., Peyron, O., Reille, M., Reynaud-Farrera, I., Riollet, G., Ritchie, J. C., Roche, E., Scott, L., Ssemmanda, I., Straka, H., Umer, M., Van Campo, E., Vilimumbalo, S., Vincens, A., and Walleret, M.: Biome reconstruction from pollen and plant macrofossil data for Africa and the Arabian peninsula at 0 and $6 \mathrm{ka}$, J. Biogeogr., 25, 1007 1027, 1998.

Joussaume S. and PMIP members: Monsoon changes for 6000 years ago: Results of 18 simulations from the Paleoclimate Modeling Intercomparison Project (PMIP), Geophys. Res. Lett., 26, 859-862, 1999.

Kohfeld, K. E. and Harrison, S. P.: How well can we simulate past climates? Evaluating the models using global palaeooenviron- 
mental data sets, Quat. Sci. Rev., 19, 321-346, 2000.

Kutzbach, J. E. and Guetter, P. J.: The influence of changing orbital parameters and surface boundary conditions on climate simulation for the past 18000 years, J. Atmos. Sci., 43, 1726-1759, 1986.

Kutzbach, J. E. and Liu, Z.: Oceanic feedback on the western African monsoon at 6000 BP, Science, 278, 440-443, 1997.

Kutzbach, J. E. and Otto-Bliesner, B. L.: The sensitivity of the African-Asian monsoonal climate to orbital parameter changes for $9000 \mathrm{yr}$ B. P. in a low-resolution general circulation model, J. Atmos. Sci., 39, 1177-1188, 1982.

Lehmkuhl, F.: Late Pleistocene, late-glacial and Holocene glacier advances on the Tibetan Plateau, Quatern. Int., 38-39, 77-83, 1997.

Lehmkuhl, F. and Oven, L. A: Late Quaternary glaciation of Tibetan and the bordering mountains: a review, Boreas, 34, 87$100,2005$.

Liu, Z., Otto-Bliesner, B. L., Kutzbach, J. E., Li, L., and Shields, C.: Coupled climate simulation of the evolution of global monsoons in the Holocene, J. Clim., 16, 2472-2490, 2003.

Maxwell, A. L.: Holocene changes inferred from lake sediments pollen and carbonate records, northeastern Cambodia, Quaternary Res., 56, 390-400, 2001.

Mayewski, P. A., Rohling, E. E., Starge, J. C., Karlen, W., Maasch, K. A., Meeker, L., Meyerson, E. A., Gasse, F. G., Kreveld, S. V., Holmgren, K., Thorp, J. L., Rosqvist, G., Rack, F., Staubwasser, M., Schneider, R. R., and Steig, E. J.: Holocene climate variability, Quaternary Res., 62, 243-255, 2004.

Molnar P. and England, P.: Late Cenozoic uplift of mountain ranges and global climatic change: Chicken or egg?, Nature, 246, 2934, 1990.

Morrill, C., Overpeck, J. T., and Cole, J. E.: A synthesis of abrupt changes in the Asian summer monsoon since the last deglaciation, Holocene, 13, 465-476, 2003.

Otto-Bliesner, B. L.: El Nino/La Nina and Sahel precipitation during the middle Holocene, Geophys. Res. Lett., 26, 87-89, 1999.

Oven, L. A.: Latest Pleistocene and Holocene glacier fluctuations in the Himalaya and Tibet, Quaternary Sci. Rev., doi:10.1016/j.quascirev.2008.10.020, in press, 2009.

Petoukhov, V., Ganopolski, A., Brovkin, V., Claussen, M., Eliseev, A., Kubatzki, C., Rahmstorf, S.: CLIMBER-2: A climate system model of intermediate complexity. part I: Model description and performance for present climate, Clim. Dyn., 16, 1-17, 2000.

Phadtare, N. R.: Sharp decrease in summer monsoon strength 4000-3500 cal yr B. P. in the central higher Himalaya of India based on pollen evidence from Alpine peat, Quaternary Res., 53, 122-129, 2000.

Phillips, W. M., Sloan, V. F., Sharma, P., Clarke, M. L., and Rendell, H. M.: Asynchronous glaciation at Nanga Parbat, northwestern Himalaya Mountains, Pakistan, Geology, 28, 431-433, 2000.

Prell, W. and Kutzbach, J.: Sensitivity of the Indian monsoon to forcing parameters and implications for its evolution, Nature, 360, 647-652, 1992.

Qin, D. H.: Assessment of Environmental Changes in Western China - Integration Report, Beijing, Science Press, 5-6, 2002.

Ruddiman, W. F. and Kuzbach, J. E.: Forcing of late Cenozoic Northern Hemisphere climate by plateau uplift in southern Asia and the American west, J. Geophys. Res., 94, D15, 18409$18427,1989$.
Sharma, S., Joachimiski, M., Sharma, M., Tobschall, H. J., Singh, I. B., Sharma, C., Chauhan, M. S., and Morgenroth, G.: Late glacial and Holocene environmental changes in Ganga plain, northern India, Quaternary Sci. Rev., 23, 145-159, 2004.

Singh, I. B.: Late Quaternary evolution of Ganga Plain and proxy records of climate change, neotectonics and anthropogenic activity, Pragdhara, 12, 1-25, 2002.

Singh, G., Wasson, R. J., and Agarwal, D. P.: Vegetational and seasonal climatic changes since the last full glacier in the Thar desert, northwestern India, Rev. Palaeobot. Palynol., 64, 351358, 1990.

Srivastava, P., Singh, I. B., Sharma, S., Shukla, U. K., and Singhvi, A. K.: Late Pleostocene-Holocene hydrologic changes in the interfluve areas of the central Ganga Plain, India, Geomorphology, 54, 279-292, 2003.

Staubwasser, M., Sirocko, F., Grootes, P. M., and Segl, M.: Change at the $4.2 \mathrm{ka}$ BP termination of the Indus Valley civilization and Holocene south Asian monsoon variability, Geophys. Res. Lett., 30(8), 1425, doi:10.1029/2002GL016822, 2003.

Stocker, T. F., Wright, D. G., and Mysak, L. A.: A zonally averaged, coupled ocean-atmosphere model for the paleoclimate studies, J. Clim., 5, 773-797, 1992.

TEMPO Members: Potential role of vegetation feedback in the climate sensitivity of high-latitude regions: A case study at 6000 years B.P., Global Biogeochem., Cycles, 10, 727-736, 1996.

Texier, D., de Noblet, N., Harrison, S. P., Haxeltine, A., Jolly, D., Joussaume, S., Laarif, F., Prentice, I. C., Tarasov, P.: Quantifying the role of biosphere-atmosphere feedbacks in climate change: coupled model simulations for 6000 years BP and comparison with palaeodata for northern Eurasia and northern Africa, Clim. Dyn., 13, 865-882, 1997.

Thompson, L. G., Yao, T., Davis, M. E., Henderson, K. A., MosleyThompson, E., Lin, P. N., Beer, J., Synal, H. A., Cole-Dai, J., and Bolzan, J. F.: Tropical climate instability: The last glacial cycle from a Qinghai-Tibetan ice core, Science, 276, 1821-1825, 1997.

Thompson, L.G., Yao, T., Mosley-Thompson, E., Davis, M. E., Henderson, K. A., and Lin, P. N.: A high-resolution millennial record of the south Asian monsoon from Himalayan ice cores, Science, 289, 1916-1919, 2000.

Thompson, L. G., Mosley-Thompson, E., Davis, M. E., Mashiotta, T. A., Henderson, K. A., Lin, P. N., and Yao, T.: Ice core evidence for asynchronous glaciation on the Tibetan Plateau, Quatern. Int., 154-155, 3-10, 2006.

Tang, L., Shen, C., Liu, K. B., and Overpeck, J. T.: Changes in south Asian monsoon: new high-resolution paleoclimatic records from Tibet, Chin. Sci. Bull., 45, 87-91, 2000.

Wang, H. J.: Role of vegetation and soil in the Holocene megathermal climate over China, J. Geophys. Res., 104, 9361-9367, 1999.

Weber, S. L. and Oerlemans, J.: Holocene glacier variability: three case studies using an intermediate-complexity climate model, The Holocene, 13(3), 353-363, 2003.

Weber, S. L., Crowley, T. J., and van der Schrier, G.: Solar irradiance forcing of centennial climate variability during the Holocene, Clim. Dyn., 22, 539-553, 2004.

Webster, P. J. and Yang, S.: Monsoon and ENSO: Selectively interactive systems, Q. J. Roy. Meteor. Soc., 118, 877-926, 1992.

Yanai, M., Li, C., and Song, Z.: Seasonal heating of the Tibetan 
Plateau and its effects on the evolution of the summer monsoon, J. Meteorol. Soc. Jpn., 70, 319-351, 1992.

Yang, B., Brauning, A., Dong, Z., Zhang, Z., and Jiao, K.: Late Holocene monsoonal temperature glacier fluctuations on the Tibetan Plateau, Global Planet. Change, 60(1-2), 126-140, doi:10.1016/j.gloplacha.2006.07.035, 2008.
Yao, T. D., Liu, X. D., and Wang, N. L.: On amplitudes of climatic variation in Qinghai-Tibetan Plateau, Chin. Sci. Bull., 45, 98 106, 2000 (in Chinese). 